\title{
Analisis Kesalahan Ejaan Pada Skripsi Mahasiswa Program Studi Pendidikan Olahraga Dan Kesehatan
}

\author{
Supriadin \\ Dosen Universitas Pendidikan Mandalika \\ Supriadin.undikma@gmail.com
}

\begin{abstract}
Abstrak: Penelitian ini bertujuan untuk mendeskripsikan (1) kesalahan huruf kapital, (2) kesalahan penulisan kata depan dan imbuhan, (3) kesalahan penulisan unsur serapan, dan (4) kesalahan pemakaian tanda baca pada skripsi mahasiswa Program Studi Pendidikan Olahraga dan Kesehatan. Untuk memperdalam dan lebih fokus, maka sampel penelitian ini berjumlah tiga skripsi mahasiswa tahun 2020. Penggumpulan data dilakukan dengan teknik membaca dan mencacat, sedangkan instrumen pengumpulan data dengan menggunakan human instrument, yaitu peneliti sendiri. Teknik analisis data dilakukan dengan teknik analisis deskriptif kualitatif. Keabsahan data diperoleh dengan cara intrarater dan interrater. Hasil penelitian ini menunjukkan bahwa kesalahan ejaan pada skripsi mahasiswa Program Studi Pendidikan Olahraga dan Kesehatan Universitas Pendidikan Mandalika sebanyak 247 kesalahan yang terdiri: (1) kesalahan pemakaian huruf kapital sebanyak 8 kesalahan, (2) kesalahan penulisan kata depan di dan ke sebanyak 30 kesalahan, yang meliputi kesalahan penulisan kata depan $d i$ sebanyak 28 kesalahan, kesalahan penulisan kata depan $k e$ sebanyak 2 kesalahan, sedangkan imbuhan $d i$-, ke-, dan kata depan dari tidak ditemukan kesalahan pada skripsi mahasiswa, (3) kesalahan pemakaian tanda baca sebanyak 209 kesalahan, yang meliputi kesalahan pemakaian tanda baca titik (.) sebanyak 34 kesalahan, kesalahan pemakaian tanda baca koma (,) sebanyak 163 kesalahan, kesalahan pemakaian tanda hubung (-) sebanyak 1 kesalahan, kesalahan pemakaian tanda tanya (?) sebanyak 4 kesalahan, dan kesalahan pemakaian tanda baca titik dua (:) sebanyak 8 kesalahan, dan (4) kesalahan pemakaian tanda seru (!), kesalahan pemakaian tanda baca titik koma (;), kesalahan pemakaian tanda petik tunggal ('...'), kesalahan pemakaian tanda petik (“...”), dan kesalahan pemakaian tanda garis miring (/) tidak ditemukan kesalahan.
\end{abstract}

Kata Kunci: Analisis Kesalahan Ejaan, Srkripsi Mahasiswa, Pendidikan Olahraga dan Kesehatan

\section{PENDAHULUAN}

Penggunaan bahasa yang benar menurut kaidah Pedoman Umum Ejaan Bahasa Indonesia (PUEBI) merupakan salah satu faktor yang sangat penting dalam hal tulis-menulis. Pemilihan kata berhubungan erat dengan kaidah sintaksis, kaidah makna, kaidah hubungan sosial, dan kaidah mengarang. Kaidah-kaidah ini sering mendukung sehingga tulisan menjadi lebih berstruktur dan bernilai, serta lebih mudah dipahami dan dimengerti oleh orang lain. Namun pada kenyataannya, masih banyak kesalahan pada penggunaan ejaan.

Dalam hal ini, peneliti menemukan beragam kesalahan yang dapat ditemukan dalam skripsi mahasiswa Program Studi Pendidikan Olahraga dan Kesehatan Universitas Pendidikan Mandalika (UNDIKMA) menjadi salah satu pembuktian bahwa mahasiswa Program Studi Pendidikan Olahraga dan Kesehatan masih banyak ditemukan kesalahan dalam penggunaan bahasa terutama dalam hal ejaan dalam menulis sebuah skripsi. Padahal mahasiswa dituntut untuk menerapkan ejaan yang benar sesuai dengan kaidah PUEBI.

Melalui kegiatan menulis tugas akhir skripsi mahasiswa dilatih untuk terampil menerapkan aspek kebahasaan, seperti kosa kata, tata bahasa, ejaan, dan tata bunyi. Dalam kaitannya dengan aspek kebahasaan khususnya ejaan, mahasiswa dituntut untuk menerapkan ejaan yang benar setiap dalam penulisan.

Ejaan sering disebut ortografi. Ejaan yang digunakan dalam bahasa Indonesia saat ini dikenal dengan sebutan Pedoman Umum Ejaan Bahasa Indonesia (PUEBI). Ejaan yang disempurnakan ini berlaku sejak tahun 2015. Ejaan ini menggantikan ejaan sebelumnya, seperti ejaan Ch. A. Van Ophuijsen (1901), ejaan 
Suwandi (1947), ejaan 1966, dan ejaan yang disempurnahkan (1972).

Pedoman Umum Ejaan Bahasa Indonesia ini terdiri atas empat bab, yaitu (1) pemakaian huruf, (2) penulisan kata, (3) pemakaian tanda baca, dan (4) penulisan unsur serapan. Dalam bahasa tulis sering ditemukan kesalahan pemakaian ejaan. Penyebabnya antara lain penulis masih kurang paham mengenai ejaan, kurang terbiasa menggunakan ejaan, maupun faktor lingkungan penulis.

Kesalahan ejaan termasuk salah satu jenis kesalahan berbahasa dalam bahasa tulis. Hal itu sangat mempengaruhi kualitas sebuah tulisan. Suatu tulisan yang sudah sempurna menurut segi isi belum tentu dapat dikatakan tulisan yang baik. Apabila banyak kesalahan ejaan dan tanpa memperhatikan ejaan yang benar, isi tulisan tidak dapat disampaikan kepada pembaca secara jelas dan tepat.

Kesalahan ejaan tersebut juga masih ditemukan pada skripsi mahasiswa Program Studi Pendidikan Olahraga dan Kesehatan Universitas Pendidikan Mandalika (UNDIKMA). Oleh karena itu, penulis ini dilakukan untuk mengetahui tingkat kesalahan ejaan dalam skripsi mahasiswa Program Studi Pendidikan Olahraga dan Kesehatan. Dengan demikian, akan diketahui secara rinci bagaiman tingkat ejaan yang benar dalam skripsi mahasiswa Program Studi Pendidikan Olahraga dan Kesehatan Universitas Pendidikan Mandalika (UNDIKMA) sehingga akan diketahui kemampuan mahasiswa dalam kegiatan menulis skripsi dengan ejaan yang benar.

\section{METODE PENELITIAN}

Penelitian ini dilakukan dengan menggunakan pendekatan kualitatif yang termasuk dalam penelitian kebahasaan. Pendekatan kualitatif dipilih karena masalah yang diteliti berupa data (skripsi) yang lebih tepatnya dijelaskan dengan menggunakan katakata.

Subjek penelitian ini adalah hasil penelitian ada skripsi mahasiswa Program Studi Pendidikan Olahraga dan Kesehatan Universitas Pendidikan Mandalika (UNDIKMA). Alasan dipilihnya skripsi mahasiswa Program Studi Pendidikan
Olahraga dan Kesehatan Universitas Pendidikan Mandalika (UNDIKMA) dengan mempertimbangkan bahwa penelitian serupa belum pernah dilakukan.

Objek penelitian ini adalah ejaan dalam skripsi tahun 2020, skripsi A, B, dan C. Untuk memperdalam dan lebih fokus, maka jumlah skripsi yang dianalisis berjumlah 3 skripsi mahasiswa Program Studi Pendidikan Olahraga dan Kesehatan Universitas Pendidikan Mandalika (UNDIKMA). Ejaan tersebut meliputi kesalahan pemakaian huruf kapital, kesalahan penulisan kata depan di, ke dan imbuhan $d i$ - dan $k e$-, penulisan unsur serapan, dan penulisan tanda baca.

Teknik pengumpulan data dalam penelitian ini menggunakan teknik baca. Teknik baca yang dilakukan adalah membaca secara berulang dan cermat skripsi mahasiswa Program Studi Pendidikan Olahraga dan Kesehatan Universitas Pendidikan Mandalika (UNDIKMA) yang telah dipilih. Pembacaan disesuaikan dengan tujuan penulis, sedangkan yang tidak berhubungan dengan penulis ini diabaikan. Teknik selanjutnya yang dilakukan dalam penelitian ini adalah teknik catat. Taknik catat ini digunakan untuk mengungkapkan suatu permasalahan yang terdapat dalam suatu bacaan atau wacana (Sudaryanto, 1999: 41). Sebelum dilakukan pencatatan, terlebih dahulu dilakukan pencatatan data pada kartu data, kemudian kartu data tersebut dikategorikan menurut kriteria kesalahan ejaan. Data yang terkumpul, kemudian dianalisis dan dideskripsikan.

Setelah dianalisis dan dideskripsikan, selanjutnya kesalahan yang telah ditemukan tersebut dibetulkan. Pembetulan kesalahan dalam penelitian ini bersifat parsial. Artinya, pembetulan hanya pada bagian yang berkaitan dengan penelitian, yaitu berupa ejaan tertentu yang dibatasi pada kesalahan pemakaian huruf kapital, kesalahan penulisan imbuhan di-, ke-, dan kata depan di, ke, dari, dan kesalahan penggunaan tanda baca.

Instrumen pengumpulan data ini adalah menggunakan human instrument yaitu peneliti sendiri. Peneliti sebagai pelaksana yang akan mengumpulkan data, menganalisis, dan sekaligus membuat kesimpulan. Pengetahuan peneliti tentang ejaan menjadi alat penting dalam 
penelitian ini. Dalam hal ini, peneliti menentukan kriteria-kriteria kesalahan ejaan dalam skripsi mahasiswa Program Studi Pendidikan Olahraga dan Kesehatan Universitas Pendidikan Mandalika (UNDIKMA). Dengan menggunakan kriteria tersebut, peneliti akan menganalisis ejaan pada skripsi mahasiswa Program Studi Pendidikan Olahraga dan Kesehatan Universitas Pendidikan Mandalika (UNDIKMA) untuk menentukan terdapat atau tidaknya kesalahan ejaan.

1. Kesalahan penggunaan huruf kapital.

2. Kesalahan penulisan imbuhan $d i-$, $k e-$ dan kata depan $d i$, ke, dan dari.

3. Kesalahan penulisan unsur serapan.

4. Kesalahan penggunaan tanda baca, meliputi tanda titik (.), tanda koma (,), tanda titik dua $(:)$, tanda titik koma (;), tanda hubung (-), tanda tanya (?), tanda seru (!), tanda kurung $((\ldots))$, tanda petik (“...”), tanda petik tunggal ('..'), dan tanda garis miring (/).

Untuk mendapatkan keabsahan data, yaitu dengan cara mencermati berulang-ulang skripsi mahasiswa Program Studi Pendidikan Olahraga dan Kesehatan Universitas Pendidikan Mandalika (UNDIKMA) untuk menentukan data sebanyak-banyaknya dan aspek yang relevan dengan permasalahan yang diteliti sehingga mendapatkan data yang benar-benar akurat dan normal. Pengamatan berulang-ulang dan mendalam terhadap skripsi mahasiswa Program Studi Pendidikan Olahraga dan Kesehatan Universitas Pendidikan Mandalika (UNDIKMA) untuk mendapatkan hasil penelitian yang valid.

Analisis data merupakan upaya peneliti menagani langsung masalah yang terkandung dalam data (Sudaryanto, 2001: 3-6). Penanganan itu tampak dari adanya tindakan mengamati, membedah, atau mengurangi, dan menguraikan masalah yang bersangkutan dengan cara khas tertentu. Cara-cara khas tertentu yang ditempuh peneliti untuk memahami problematika suatu kebahasaan yang diangkat sebagai objek penelitian ini disebut metode analisis data (Sudaryanto, 2001: 57).

Dalam tahap ini, untuk memperoleh deskripsi bentuk kesalahan ejaan digunakan metode padan dan agih (distribusional). Metode padan digunakan untuk menganalisis sekaligus menafsirkan peristiwa-peristiwa berbahasa yang berkaitan dengan faktor penentuan penggunaan bahasa yang alat penentunya berupa bahasa tulis.

\section{HASIL PENELITIAN DAN PEMBAHASAN \\ 1. Hasil Penelitian}

Hasil penelitian yang akan disajikan di sini adalah berupa analisis kesalahan ejaan pada beberapa skripsi mahasiswa Program Studi Pendidikan Olahraga dan Kesehatan Universitas Pendidikan Mandalika (UNDIKMA). Jenis kesalahan ejaannya, yaitu pemakaian huruf, pemakaian huruf kapital dan huruf miring, penulisan kata, penulisan unsur serapan, dan pemakaian tanda baca.

Hasil skripsi tersebut diidentifikasi berdasarkan jenis kesalahannya. Hasil identifikasi kesalahan-kesalahan ejaan yang diperoleh, kemudian diolah melalui teknik kerja analisis data. Data yang diperoleh dengan teknik membaca tiap kalimat dan mencatat kalimat yang ejaannya salah, kemudian dimasukkan dalam kartu data dan dianalisis dengan teknik deskripsi kualitatif.

Berdasarkan batasan di atas, hasil penelitian kesalahan ejaan pada beberapa skripsi mahasiswa prodi Bahasa dan Sastra Indonesia Universitas Negeri Yogyakarta diperoleh kesalahan sebanyak 247 kasus kesalahan, yang meliputi: (1) kesalahan pemakaian pemakaian huruf kapital berjumlah 8 kesalahan, (2) kesalahan kata depan di dan ke berjumlah 30 kesalahan, (3) kesalahan pemakaian tanda baca berjumlah 209 kasus kesalahan dan (4) kesalahan penulisan unsur serapan tidak ditemukan kesalahan. Berikut ini tabel frekuensi dan persentase jenis kesalahan ejaan pada skripsi mahasiswa Program Studi Pendidikan Olahraga dan Kesehatan Universitas Pendidikan Mandalika (UNDIKMA).

Tabel 1. Persentasi Kesalahan Ejaan pada skripsi mahasiswa Program Studi Pendidikan Olahraga dan Kesehatan Universitas Pendidikan Mandalika (UNDIKMA).

\begin{tabular}{|c|l|c|c|}
\hline No & $\begin{array}{c}\text { Aspek Kesalahan } \\
\text { Ejaan }\end{array}$ & Frekuensi & Persentase \\
\hline 1 & Pemakaian Huruf & 8 & $3,24 \%$ \\
\hline 2 & $\begin{array}{l}\text { Penulisan Kata di dan } \\
k e\end{array}$ & 30 & $12,15 \%$ \\
\hline 3 & Peulisan Tanda Baca & 209 & $84,61 \%$ \\
\hline 4 & $\begin{array}{l}\text { Penulisan Usur } \\
\text { Serapan }\end{array}$ & - & - \\
\hline & Jumlah & 247 & $100 \%$ \\
\hline
\end{tabular}


Dari tabel di atas dapat dilihat bahwa jumlah kesalahan yang paling banyak ditemukan adalah penggunaan tanda baca.

\section{Pembahasan}

Pembahasan penelitian ini adalah kesalahan ejaan pada skripsi mahasiswa Program Studi Pendidikan Olahraga dan Kesehatan Universitas Pendidikan Mandalika (UNDIKMA) didasarkan pada hasil analisis. Pembahasan ini dilakukan sebagaimana pengelompokan kesalahan ejaan yang terdiri atas kesalahan pemakaian huruf, pemakaian huruf kapital dan huruf miring, penulisan kata, penulisan unsur serapan, dan pemakaian tanda baca. Adapun pembahasan hasil penelitian tersebut adalah sebagai berikut.

\section{a. Penggunaan Huruf Kapital}

Kesalahan ejaan pada karangan disebabkan oleh kesalahan penggunaan huruf kapital. Dalam penelitian ini terdapat 8 kesalahan penggunaan huruf kapital dalam skripsi mahasiswa Program Studi Pendidikan Olahraga dan Kesehatan Universitas Pendidikan Mandalika (UNDIKMA). Kesalahan pemakaian huruf capital pada skripsi tersebut diantaranya kurang paham dalam menggunakan huruf kapital. Kesalahan-kesalahan tersebut antara lain meliputi kesalahan pemakaian huruf kapital pada huruf pertama kata pada awal kalimat, unsur-unsur nama diri geografi atau nama negara, daerah dan kota, serapan bahasa asing, huruf pertama nama bahasa, dan huruf kapital pada huruf pertama di sebuah judul atau sub judul. Berikut ini data yang menunjukan kesalahan penggunaan huruf kapital yang terdapat pada skripsi mahasiswa Program Studi Pendidikan Olahraga dan Kesehatan Universitas Pendidikan Mandalika (UNDIKMA).

(1) "atau bagian-bagian tertentu dalam karya sastra yang dalam bahasa inggris disebut dengan atmosphere." (A/29/07/20)

(2) "apabila orang hanya sekedar melihat sampulnya saja, maka...”(A/71/07/20)

(3) "...di bawah lema. satu lema dengan..." (B/12/08/20)

(4) "dengan hormat supaya diberi ampunan karena..." (C/12/08/20)

Pada kalimat (1) penulisan huruf $a$ pada kata atau digunakan huruf kecil yang seharusnya digunakan huruf kapital karena merupakan huruf pertama pada awal kalimat. Dengan semikian, ejaan yang sesuai dengan kalimat (1) adalah sebagai berikut.

(1a) "atau bagian-bagian tertentu dalam karya sastra yang dalam bahasa Inggris disebut dengan atmosphere." (A/29/07/20)

Pada kalimat (2) huruf $a$ pada kata apabila seharusnya memakai huruf kapital karena huruf $a$ pada kata apabila adalah huruf pertama kata pada awal kalimat. Dengan demikian, ejaan yang sesuai dengan kalimat (2) adalah sebagai berikut.

(2a) "Apabila orang hanya sekedar melihat sampulnya saja, maka..." (A/71/04/02)

Pada kalimat (3) huruf $s$ pada kata satu seharusnya memakai huruf kapital karena huruf $s$ pada kata satu adalah huruf pertama kata pada awal kalimat. Dengan demikian, ejaan yang sesuai dengan kalimat (3) adalah sebagai berikut.

(3a) “..., di bawah lema. satu lema dengan..." (B/12/08/20)

Pada kalimat (4) huruf $d$ pada kata dengan seharusnya memakai huruf kapital karena huruf $d$ pada kata dengan adalah huruf pertama kata pada awal kalimat. Dengan demikian, ejaan yang sesuai dengan kalimat (4) adalah sebagai berikut.

(4a) "dengan hormat supaya diberi ampunan karena..." (C/12/08/20)

\section{b. Penulisan Imbuhan di-, ke- dan Kata \\ Depan di, ke, dan dari}

Masih ada mahasiswa BSI yang sulit dalam membedakan antara di- dan ke- sebagai imbuhan dan $d i, k e$, dan dari sebagai kata depan. Imbuhan $d i$ - dan $k e$ - sebagai kata imbuhan berpadan dengan kata kerja dan ditulis serangkai dengan kata dasarnya. Sementara itu, kata depan $d i$, ke, dan dari berpadan dengan kata benda dan menunjukan keterangan tempat. Dalam penelitian ini terdapat 30 kesalahan penggunaan imbuhan di-, ke, dan kata depan di, ke, dan dari, yang terdiri dari atas 28 kesalahan kata depan $d i$, 2 kesalahan penggunaan kata depan $k e$, sedangkan penulisan kata depan dari, imbuhan $d i$ - dan $k e$ - tidak ditemukan kesalahan. 


\section{1) Penulisan Kata Depan di}

Berikut ini data yang menunjukkan kesalahan ejaan yang disebabkan oleh kesalahan penulisan kata depan $d i$.

(5) "...dibawah lema. Satu lema dengan yang,..." (B/12/06/03)

(6) "...ditentukan oleh tingkat pendidikan dimana kamus itu digunakan.” (B/31/01/01)

(7) "Kasus pelanggaran prinsip kerja sama diatas menunjukkan..."(C/01/03/01)

(8) "Yang dimaksud menarik disini karena dalam status..." (C/05/01/02)

(9) "...karena didalam rubrik ini terdapat..." $(\mathrm{D} / 04 / 02 / 01)$

(10) "...mendukung register khusus dibidang seksual..." (D/62/01/01)

Pada kalimat (5) kata depan di pada kata dibawah seharusnya ditulis terpisah dari kata yang mengikutinya. Dengan demikian, penulisan kata depan $d i$ yang sesuai dengan kalimat (5) adalah sebagai berikut.

(5a) "... di bawah lema. Satu lema dengan yang..."

Pada kalimat (6) kata depan di pada kata dimana seharusnya ditulis terpisah dari kata yang mengikutinya. Dengan demikian, penulisan kata depan $d i$ yang sesuai dengan kalimat (6) adalah sebagai berikut.

(6a) "...ditentukan oleh tingkat pendidikan di mana kamus itu digunakan."

Pada kalimat (7) kata depan di pada kata diatas seharusnya ditulis terpisah dari kata yang mengikutinya. Dengan demikian, penulisan kata depan $d i$ yang sesuai dengan kalimat (7) adalah sebagai berikut.

(7a) "Kasus pelanggaran prinsip kerja sama di atas menunjukkan..."

Pada kalimat (8) kata depan di pada kata disini seharusnya ditulis terpisah dari kata yang mengikutinya. Dengan demikian, penulisan kata depan di yang sesuai dengan kalimat (8) adalah sebagai berikut.

(8a) "Yang dimaksud menarik di sini karena dalam status,..."

Pada kalimat (9) kata depan di pada kata didalam seharusnya ditulis terpisah dari kata yang mengikutinya. Dengan demikian, penulisan kata depan di yang sesuai dengan kalimat (9) adalah sebagai berikut.

(9a) “...karena di dalam rubrik ini terdapat, ..."
Pada kalimat (10) kata depan di pada kata dibidang seharusnya ditulis terpisah dari kata yang mengikutinya. Dengan demikian, penulisan kata depan di yang sesuai dengan kalimat (12) adalah sebagai berikut.

(10a) "...mendukung register khusus di bidang seksual..."

\section{2) Penulisan Kata Depan ke}

Berikut ini data yang menunjukkan kesalahan ejaan yang disebabkan oleh kesalahan penulisan kata depan $k e$.

(11) “...Herlinatiens memang sedikit memasukkan unsur homoseks kedalam karyanya." (A/71/04/03)

(12) "Yang termasuk kedalam kamus terbatas ini..." (B/31/02/03)

(13) "...letak geografis suatu daerah tidak dimasukkan kedalam kamus." (B/42/01/ 06)

(14) “...namun istilah tersebut akan dikategorikan kedalam..."(D/59/01/03)

Pada kalimat (11) samapai (14) kata depan $k e$ ditulis serangkai dengan kata kedalam yang seharusnya ditulis terpisah dari kata yang mengikutinya karena ke pada kata tersebut sebagai kata depan. Dengan demikian, penulisan $k e$ yang sesuai dengan kalimat (11) sampai (14) adalah sebagai berikut.

(11a) ...Herlinatiens memang sedikit memasukkan unsur homoseks ke dalam karyanya.

(12a) "Yang termasuk ke dalam kamus terbatas ini,..."

(13a) "...letak geografis suatu daerah tidak dimasukkan ke dalam kamus."

(14a) "...namun istilah tersebut akan dikategorikan ke dalam..."

\section{3) Penggunaan Tanda Baca}

Masih banyak kesalahan pemakaian tanda baca yang terdapat pada skripsi mahasiswa Program Studi Pendidikan Olahraga dan Kesehatan Universitas Pendidikan Mandalika (UNDIKMA) karena tidak sesuai dengan konteks kalimatnya. Dalam penelitian ini terdapat 209 kesalahan penggunaan tanda baca, meliputi 34 kesalahan tanda baca titik (.), 163 kesalahan penggunaan tanda baca koma (,), 1 kesalahan penggunaan tanda hubung (-), 4 kesalahan penggunaan tanda tanya (?), dan 7 kesalahan tanda baca titik dua (:). Sementara itu, 
kesalahan penggunaan tanda baca seru (!), kesalahan tanda petik tunggal ('...'), kesalahan tanda baca titik koma (;), kesalahan penggunaan tanda petik dua (“..."), dan kesalahan penggunaan tanda baca garis miring (/) tidak ditemukan kesalahan.

\section{a. Penggunaan Tanda Titik (.)}

Berikut ini data yang menunjukkan kesalahan ejaan yang disebabkan oleh penggunaan tanda baca titik yang tidak tepat.

(15) "...hingga menjadi suatu kebulatan menurut ukuran-ukuranku (1982: 80)." $(\mathrm{A} / 12 / 01 / 03)$

(16) “...akan menghasilkan sumber latihan berpikir yang tiada habisnya (Sayuti, 2003: 72)." (A/14/04/03)

(17) "Contoh Reduksi Data:" (C/34/01/ 04)

(18) "Misalnya, register dokter, register petani, atau pertanian, register pendidikan (Parera, 1993: 53)." (D/15 /02/05)

(19) “...dengan membesar-besarkan sesuatu hal (jumlahnya, ukurannya, atau sifatnya)." (D/29/02/01)

Pada kalimat (15) sampai (19) tidak digunakan tanda baca titik (.) pada akhir kalimat yang seharusnya dipakai pada akhir kalimat yang bukan pertanyaan atau seruan. Dengan demikian, ejaan yang sesuai dengan kalimat di atas adalah sebagai berikut.

(15a) "...hingga menjadi suatu kebulatan menurut ukuran-ukuranku. (1982: 80)."

(16a) “...akan menghasilkan sumber latihan berpikir yang tiada habisnya (Sayuti, 2003: 72)."

(17a) "Contoh Reduksi Data."

(18a) "Misalnya, register dokter, register petani, atau pertanian, register pendidikan (Parera, 1993: 53)."

(19a) "...dengan membesar-besarkan sesuatu hal (jumlahnya, ukurannya, atau sifatnya)."

\section{b. Penggunaan Tanda Koma (,)}

Berikut ini data yang menunjukkan kesalahan ejaan yang disebabkan oleh penggunaan tanda baca koma (,) yang tidak tepat.

(20) "Selain itu pendidikan ini juga bertujuan..." (A/viii/01/02)

(21) "Sedangkan data sekunder diperoleh dari semua teks novelnya yang berjudul

\section{Sebuah Cinta yang Menangis”.} (A/viii/02/06)

(22) "...yaitu singkatan, angkronim dan kontraksi." (B/07/01/08)

(23) "Penataan prinsip kerja sama terjadi jika peserta tutur..."(C/02/01/05)

(24) "...bahasa yang kacau, baik struktur kata, kalimat maupun penggunaan kata..." (D/03/01/05)

(25) “...seperti konsultasi kesehatan, keuangan, keluarga, psikologi bahkan sampai pada,..." (D/03/02/02)

Pada kalimat (20) dan (21) tidak digunakan tanda koma yang seharusnya dipakai untuk ungkapan penghubung antarkalimat yang terdapat pada awal kalimat. Dengan demikian, ejaan yang sesuai dengan kalimat (20) dan (21) adalah sebagai berikut. (20a) "Selain itu, pendidikan ini juga bertujuan..."

(21a) "Sedangkan data sekunder, diperoleh dari semua teks novelnya yang berjudul Sebuah Cinta yang Menangis."

Pada kalimat (22) tidak digunakan tanda koma yang seharusnya dalam kalimat ini tanda baca koma dipakai di antara unsur-unsur dalam suatu perincian atau pembilangan. Dengan demikian, ejaan yang sesuai dengan kalimat (22) adalah sebagai berikut.

(22a) "...yaitu singkatan, angkronim, dan kontraksi."

Pada kalimat (23) tidak digunakan tanda koma yang seharusnya dipakai di belakang kata atau yang menghubungkan antarkalimat. Dengan demikian, ejaan yang sesuai dengan kalimat (23) adalah sebagai berikut.

(23a) "Penataan prinsip kerja sama terjadi, jika peserta tutur..."

Pada kalimat (24) dan (25) tidak digunakan tanda koma yang seharusnya dalam kalimat ini tanda baca koma dipakai di antara unsur-unsur dalam suatu perincian atau pembilangan. Dengan demikian, ejaan yang sesuai dengan kalimat (28) dan (29) adalah sebagai berikut.

(24a) “...bahasa yang kacau, baik struktur kata, kalimat, maupun penggunaan kata..." 
(25a) “...seperti konsultasi kesehatan, keuangan, keluarga, psikologi bahkan sampai pada..."

\section{c. Penggunaan Tanda Hubung (-)}

Berikut ini data yang menunjukkan kesalahan ejaan yang disebabkan oleh penggunaan tanda baca hubung (-) yang tidak tepat.

(26) "Cerita terdiri dari peristiwa (events) dan wujud keberadaannya eksistensinya (existents)." (A/27/02/ 02)

Pada kalimat (26) terjadi kesalahan penggunaan tanda hubung yang seharusnya tidak dipakai pada kata keber-ada-annya karena tanda hubung digunakan untuk menyambung huruf kata yang dieja satu-satu bukan seperti kata tersebut. Dengan demikian, ejaan yang sesuai dengan kalimat (26) adalah sebagai berikut.

(26a) "Cerita terdiri dari peristiwa (events) dan wujud keberadaannya eksistensinya (existents)."

\section{d. Penggunaan Tanda Tanya (?)}

Berikut ini data yang menunjukkan kesalahan ejaan yang disebabkan oleh penggunaan tanda tanya (?) yang tidak tepat.

(27) Bagaimana penguasaan bahasa satrawan sehingga mampu mengikat pembaca. $(\mathrm{A} / 23 / 02 / 01)$

(28) Apakah pengarang belajar secara otodidak atau memang ada cara lain. (A/23/02/02)

(29) Seberapa jauh pengarang memiliki kepekaan terhadap persoalan kehidupan, baik yang menyangkut dunia maupun dunia lain. (A/23/03/01)

(30) ...apakah menaati atau melanggar prisip kerja sama. (C/06/03/02)

Pada kalimat (27) sampai (30) tidak dipakainya tanda tanya setelah akhir kalimat tanya. Dengan demikian, ejaan yang sesuai dengan kalimat (27) sampai

(30) adalah sebagai berikut.

(27a) Bagaimana penguasaan bahasa satrawan sehingga mampu mengikat pembaca?

(28a) Apakah pengarang belajar secara otodidak atau memang ada cara lain?

(29a) Seberapa jauh pengarang memiliki kepekaan terhadap persoalan kehidupan, baik yang menyangkut dunia maupun dunia lain?

(30a) ...apakah menaati atau melanggar prinsip kerja sama?

\section{e. Penggunaan Tanda Titik Dua (:)}

Berikut ini data yang menunjukkan kesalahan ejaan yang disebabkan oleh penggunaan tanda titik dua (:) yang tidak tepat.

(31) Model pendekatan yang dikemukakan Ratna (2004: 55) antara lain pendekatan biografi sastra, sosiologi sastra, dan,... (A/19/04/01)

(32) ...beberapa bagian karyanya seperti ide cerita, penokohan, jalan cerita, dan gaya bahasa yang dipakai. (A/31/02/03)

(33) Variasi tipe definisi tersebut, antara lain, a).... (B/93/05/03)

(34) ...mahasiswa Program Studi Pendidikan Olahraga dan Kesehatan Universitas Pendidikan Mandalika (UNDIKMA) angkatan 2016 terdiri atas pelanggaran maksim kuantitas... (C/152/01/02)

(35) Rubrik-rubrik dalam Tabloid Nyata antara lain Cover Story, Konsultasi... (D/42/02/03)

Pada kalimat (31) sampai (35) tidak dipakainya tanda titik dua pada akhir suatu pernyataan lengkap jika diikuti rangkaian atau pemerian. Dengan demikian, ejaan yang sesuai dengan kalimat di atas adalah sebagai berikut.

(31a) Model pendekatan yang dikemukakan Ratna (2004: 55) antara lain: pendekatan biografi sastra, sosiologi sastra, dan,...

(32a) ..., beberapa bagian karyanya seperti: ide cerita, penokohan, jalan cerita, dan gaya bahasa yang dipakai.

(33a) Variasi tipe definisi tersebut, antara lain: a)....

(34a) ..., mahasiswa Program Studi Pendidikan Olahraga dan Kesehatan Universitas Pendidikan Mandalika (UNDIKMA) angkatan 2016 terdiri atas: pelanggaran maksim kuantitas,...

(35a) Rubrik-rubrik dalam Tabloid Nyata antara lain: Cover Story, Konsultasi,... 


\section{PENUTUP}

Dalam bagian penutup ini, akan diuraikan mengenai simpulan, implikasi, dan saran.

\section{SIMPULAN}

Berdasarkan hasil penelitian, maka dapat disimpulkan sebagai berikut.

1. Kesalahan pemakaian huruf kapital pada skripsi mahasiswa Program Studi Pendidikan Olahraga dan Kesehatan Universitas Pendidikan Mandalika (UNDIKMA) ditemukan sebanyak 8 kasus kesalahan atau sebesar 3,24\%. Kesalahan huruf kapital tersebut disebabkan oleh kesalahan pemakaian huruf kapital sebagai unsur huruf pertama kata pada awal kalimat, huruf pertama nama bangsa, suku bangsa, dan bahasa, huruf pertama unsur-unsur nama geografi yang diikuti nama diri geografi, dan lain sebagainya.

2. Kesalahan penulisan kata depan $d i$, ke dan dari pada skripsi mahasiswa Program Studi Pendidikan Olahraga dan Kesehatan Universitas Pendidikan Mandalika (UNDIKMA) ditemukan sebanyak 30 kasus kesalahan atau sebanyak $12,15 \%$ yang meliputi kesalahan penulisan kata depan $d i$ sebanyak 28 kasus kesalahan dan kesalahan kata depan ke ditemukan sebanyak 2 kesalahan. Sementara itu, kata depan dari dan imbuhan $d i$-, $k e$ - tidak ditemukan adanya kesalahan. Kesalahan kata depan di dan ke disebabkan oleh ketidaktahuan penulisannya harus ditulis terpisah dari kata pengikutinya atau gabungan kata yang sudah lazim dianggap sebagai satu kata.

3. Kesalahan penggunaan tanda baca pada pada skripsi mahasiswa Program Studi Pendidikan Olahraga dan Kesehatan Universitas Pendidikan Mandalika (UNDIKMA) ditemukan sebanyak 209 kasus kesalahan atau sebesar 84,61\%, yang meliputi kesalahan penggunaan tanda baca titik (.) sebanyak 34 kesalahan, kesalahan penggunaan tanda baca koma (,) sebanyak 163 kesalahan, kesalahan penggunaan tanda hubung (-) sebanyak 1 kesalahan, kesalahan penggunaan tanda tanya (?) sebanyak 4 kesalahan, dan kesalahan penggunaan tanda titik dua (:) sebanyak 7 kesalahan. Sementara itu, kesalahan penggunaan tanda seru (!), kesalahan penggunaan tanda petik titik koma (;), kesalahan penggunaan tanda petik tunggal ('...'), kesalahan penggunaan tanda petik (“..."), dan kesalahan penggunaan garis miring (/) tidak ditemukan adanya kesalahan. Kesalahan tanda baca disebabkan adanya perbedaan persepsi dalam penggunaan tanda baca yang sesuai dengan pedoman EYD.

4. Kesalahan penulisan unsur serapan tidak ditemukan pada skripsi A, B, C, dan D

\section{Saran}

1. Mahasiswa hendaknya berusaha untuk meningkatkan pengetahuan mengenai ejaan. Pengetahuan ini dapat diperoleh dari dosen, buku, dan latihan-latihan.

2. Melihat banyak ditemukannya kesalahan khususnya kesalahan penggunaan ejaan, dosen hendaknya selalu memberikan perhatian yang lebih khusus dalam penulisan skripsi mahasiswa atau segala bentuk tulisan mahasiswa.

\section{DAFTAR PUSTAKA}

Azwardi. 2008. Menulis ilmiah: Materi Kuliah Bahasa Indonesia Umum untuk Mahasiswa. Banda Aceh: Unsyiah.

Badudu, J.S. 1995. Inilah Bahasa Indonesia yang Benar IV. Jakarta: PT Gramedia Pustaka.

Badudu, J.S. 1985. Cakrawala Bahasa Indonesia. Jakarta: Balai Pustaka.

Cristian. 2014. Skripsi sebagai Karya Ilmiah. (http://id.m.wikipedia.org/wiki/karya_ilmi ah). Diunduh pada tanggal 8 Desember 2014.

Depdiknas. 2003. Pedoman Umum Ejaan Bahasa Indonesia yang Disempurnakan \& Pedoman Umum Pembentukan Istilah. Bandung: Yrana Widya.

Depdiknas. 2008. Kamus Besar Bahasa Indonesia Pusat Bahasa(Cetakan Pertama Edisi IV). Jakarta: PT Gramedia. 
Hastuti PH, S. 2003. Sekitar Analisis Kesalahan Berbahasa Indonesia. Yogyakarta: Mitra Gama Widya.

Mustakim. 1994. Membina Kemampuan Berbahasa: Panduan ke arah Kemahiran Berbahasa. Jakarta: Gramedia Pustaka Utama.

Moleong, Lexy J. 2006. Metodologi Penelitian Kualitatif. Bandung: Rosda.

Parera, JD. 1996. Leksikio Istilah Pembelajaran Bahasa. Jakarta: Gramedia Pustaka Utama.

Sudaryanto. 2001. Metodologi dan Aneka Teknik Analisis Bahasa. Yogyakarta: Duta Wacana University Press. 